Meta

Journal des traducteurs

Translators' Journal

\title{
Translation Principles vs. Translator Strategies
}

\section{Kazem Lotfipour-Saedi}

Volume 41, numéro 3, septembre 1996

URI : https://id.erudit.org/iderudit/004015ar

DOI : https://doi.org/10.7202/004015ar

Aller au sommaire du numéro

\section{Éditeur(s)}

Les Presses de l'Université de Montréal

ISSN

0026-0452 (imprimé)

1492-1421 (numérique)

Découvrir la revue

Citer cet article

Lotfipour-Saedi, K. (1996). Translation Principles vs. Translator Strategies. Meta, 41(3), 389-392. https://doi.org/10.7202/004015ar

\section{Résumé de l'article}

Après avoir retenu un cadre théorique définitif sur la nature du langage et l'utilisation de celui-ci lors des échanges interpersonnels, on peut procéder au recensement des principes régissant le processus de traduction. Cependant, à cause de la nature peu stable de la "situation contextuelle" déterminant l'émergence de la fonction du langage, le traducteur ne peut souscrire à un ensemble fixe de principes et l'appliquer de façon rigide lors de la traduction de tous les types de textes. Il devrait plutôt se servir de tels principes comme de directives l'aidant à prendre les décisions stratégiques adéquates, adaptées aux contextes situationnels spécifiques. Dans cet article, nous tenterons d'abord de cerner la notion d'équivalence traductionnelle dans le cadre d'une approche discursive du langage. Ensuite, nous émettrons quelques hypothèses sur les stratégies qu'un traducteur serait susceptible d'adopter dans des situations contextuelles et co-textuelles particulières.
Ce document est protégé par la loi sur le droit d'auteur. L'utilisation des services d'Érudit (y compris la reproduction) est assujettie à sa politique d'utilisation que vous pouvez consulter en ligne.

https://apropos.erudit.org/fr/usagers/politique-dutilisation/ 


\title{
TRANSLATION PRINCIPLES VS. TRANSLATOR STRATEGIES
}

K. LOTFIPOUR-SAEDI

Department of English, University of Tabriz, Tabriz, Iran

\begin{abstract}
Résumé
Après avoir retenu un cadre théorique définitif sur la nature du langage et l'utilisation de celui-ci lors des échanges interpersonnels, on peut procéder au recensement des principes régissant le processus de traduction. Cependant, à cause de la nature peu stable de la "situation contextuelle» déterminant l'émergence de la fonction du langage, le traducteur ne peut souscrire à un ensemble fixe de principes et l'appliquer de façon rigide lors de la traduction de tous les types de textes. Il devrait plutôt se servir de tels principes comme de directives l'aidant à prendre les décisions stratégiques adéquates, adaptées aux contextes situationnels spécifiques.

Dans cet article, nous tenterons d'abord de cerner la notion d'équivalence traductionnelle dans le cadre d' une approche discursive du langage. Ensuite, nous émettrons quelques hypothèses sur les stratégies qu'un traducteur serait susceptible d'adopter dans des situations contextuelles et co-textuelles particulières.
\end{abstract}

\begin{abstract}
Having subscribed to a definite viewpoint on the nature of language and language use in interpersonal verbal transactions, one can set out to characterize the principles governing the translation process. But due to the highly volatile nature of the "context of situation" as a determining factor in the materialization of the language function, the translator cannot operate rigidly according to a set of principles in dealing with every text-type. He should rather use such principles as solid guidelines to make strategic decisions appropriate for every specific context of situation.

This paper will first outline the dimensions of translation equivalence within a discoursal approach to language. It will then speculate on the strategies the translator can employ in relation to specific contextual and co-textual factors.
\end{abstract}

\section{INTRODUCTION}

Translation studies literature, suggests that there are certain well-established principles which should be obeyed. In actual translation, however, more than one rendition is possible, and each rendition claims to be based on the same principles. The question may thus arise as to how a certain set of principles can lead to different translation procedures and translation products. This paper is an attempt to shed some light on this problem.

\section{STRATEGIES VS. PRINCIPLES}

In modern applied linguistics, the interlocutor's attempts at overcoming intralingual communication problems are referred to as "strategies." Learner strategies, avoidance strategies, conversational strategies, discourse strategies, so on (cf. Canale and Swain 1980). Strategies are defined as goal-oriented lines of action aimed at a certain problem, (Faerch and Kasper 1984) and communication strategies can accordingly be defined as 
actions, procedures, and approaches, on the part of interactants, to overcome the problems and obstacles in the way of communication. By looking at translation as a form of inter-lingual communication, we would like to consider the translator's attempts to somehow keep the communication channel open between the SL author and TL reader as strategies and to, thus, distinguish between translation principles and translator strategies. This distinction between the principles of translation equivalence, on the one hand, and translator strategies, on the other, would provide a convenient framework for translation studies. Most of the time, translation theories and principles of translation implicitly attribute a global nature to such theories and principles and seem to apply to translations between all languages. But the unique nature of each language system would poses a paradoxical situation. In actual translation practices whether in translating between two different languages or translating different text-types for different translation readers between the same two languages, translators may use non-identical methods and procedures. Firstly, there can hardly be global principles in translation between all languages. Secondly, if we talk of principles, they should not be breached by individual translators. The distinction we suggest between principles of TE and translator strategies would avoid such paradoxes and confusions.

Principles are well-established axioms and views on the nature of an entity. Not only are they arrived at through scientific observation of the behaviour of that entity, they are themselves seen as the distinguishing criteria for the same entity. In other words, the scientific principles of an entity, while being observationally derived from the behaviour of that entity, are themselves considered as the defining criteria for it. Any violation of the principles of an entity would thus compromise that entity itself. Strategies, on the other hand, are goal-oriented lines of action. They operate towards solving a local or global problem or achieving a goal, and this operation is carried out within the framework of certain specified principles. But they do not necessarily have to observe all these principles in their operation. Rather they manoeuvre around these principles to achieve their targeted goal or to solve a local problem; but their manoeuvring, due to their specific nature, does not compromise the underlying principles and entities.

\section{PRINCIPLES OF TRANSLATION EQUIVALENCE}

Because language is a crucial component in any translation process, principles of TE cannot, in nature, be different from the principles of language behaviour as a whole. Thus one tends to define TE and its defining principles depending on the viewpoint one adopts on language behaviour and verbal interpersonal communication and social semiotics as a whole. Structurally oriented scholars define TE in terms of formal equivalence, semantically oriented workers in terms of equivalence in meaning, cognitively oriented writers in terms of the equivalence in effect, functionally oriented authors in terms of equivalence in function and so on. But faced with the inability of any of these approaches in itself to deal with the true nature of language behaviour, the scholars engaged in language studies, have, in the last two decades, been moving towards the formulation of a more comprehensive framework for the purpose. This framework has come to be labelled as a discoursal approach to language. A detailed characterization of this approach is beyond the scope of this paper. It would suffice to note here that the discoursal approach is based on the true nature of the functioning of language in interpersonal transactions. It seeks to describe the language structure and function not as an entity in itself but in relation to many contextual and co-textual factors, defining notions such as acceptability and appropriacy accordingly, not purely in terms of linguistic accuracy but in relation to all the extra-linguistic and textual factors. It does not look at language meanings in terms of 
logical and truth-falsehood semantic rules, as did all the conventional approaches to language. It is rather interested in "situated" meaning. In other words, in discoursal approaches to language, meanings are not inherent components in language elements. They are rather arrived at in the verbal interaction process within the framework of a set of socio-cultural, interpersonal, transactional and textual factors. Meanings are negotiated by the interlocutors and the linguistic text offers only "indices" to activate this negotiation process.

Within the discoursal framework, translation is defined as the process of recreating a situation wherein the SL writer and the TL reader can interact. The TL is considered to be equivalent to the SL only when the discourse process activated by its textual indices is equivalent to the SL.

Elsewhere we have attempted to characterize the principles of TE within the discoursal framework ( $c f$. Lotfipour-Saedi 1990, 1992). We have identified the following 7 dimensions:

Vocabulary, structure, texture, degree of indirection, language variety, cognitive effect and aesthetic effect.

We shall not discuss these dimensions here and it would suffice only to note that all these 7 dimensions of the textual organizations as well as their discoursal effect should be taken into account in the formulation of principles of TE.

\section{TRANSLATOR STRATEGIES}

Up to this point we've dealt with principles of language behaviour and principles of TE. We've noted that principles of TE should necessarily be much the same as those of language behaviour. But the translator, who is supposed to operate within the framework of the TE principles, may face problems. Translator strategies, as we noted above, are lines of actions undertaken for solving such problems. Translator strategies operate according to the principles but they manoeuvre around them without in fact threatening their existence. This is also the case in ordinary intralingual communication situations. We cannot always convey $100 \%$ of what we want to convey; but this inability does not violate the underlying communication principles, because it is compensated for by the background knowledge contributed by the addressee, which helps communication to take place and avoids the breaking of the communication principles. But the degree of tolerance for this strategic manoeuvring has limits beyond which the underlying principles of communication are compromised. To give more concrete examples of translator strategies, we shall first classify them into system-oriented, genre-oriented and audienceoriented strategies.

\section{SYSTEM-ORIENTED STRATEGIES}

These are strategies which are employed to solve the problems arising from the non-isomorphic nature of the SL and TL systems. Different languages, as we know, are unique systems, and as such they may employ different textual devices (sound, meaning, grammar) for the same communication purpose. In the actual translation process, the translator may face dilemmas as to whether he should translate device-for-device or choose different TL devices to replace SL ones. To illustrate this point, we shall give a few examples:

a. In our characterization of the principles of TE, we have referred to texture and we have mentioned cohesion as one of the features contributing to the texture of text. Halliday and Hasan (1976) have categorized cohesive devices into grammatical and lexical cohesion and conjunction. Grammatical cohesion according to these authors is of three 
types: reference, ellipsis, and substitution. Now in translating a text from English into Farsi, according to the principles of TE, the English reference words should be replaced by Farsi reference words. But due to the differences in the two systems, such a reference-for-reference, translation may lead to texts which are alien to the Farsi system. In such cases, the translator may opt for other cohesive devices of equivalent cohesive value to replace the SL reference devices, for example replacing the SL reference by TL substitution, or ellipsis or even lexical cohesive devices. We call such translator decisions translator strategies. In other words, according to the principles of TE, the SL and TL texts should be equivalent in their degree of cohesion but the nonisomorphic textual features of the two language systems would not allow a direct device-for-device replacement. The translator, faced with such situations, would employ a strategy to cater for TL texture without compromising the underlying principles.

b. As a second example, we may refer to the strategies a translator may employ in translating poetry. In poetry, the SL rhyming patterns, due to their discoursal and cognitive functions cannot be neglected in TL. But at the same time, due to the differences in the sound-systems of the two languages on the one hand, and to the arbitrary nature of the sound-meaning relationships in all languages on the other, rhyming patterns cannot be rendered in translation. Faced with such a dilemma, a translator may employ a special strategy substituting other TL poetic devices of equivalent value for the SL rhyming patterns.

\section{GENRE-ORIENTED AND AUDIENCE-ORIENTED STRATEGIES}

By these, we mean the strategic manoeuvring around the TE principles oriented at the text-type or genre of the text which is being translated or at the audience or reader at which the translation is aimed.

For example, in the translation process, if the translator finds out that not all the afore-mentioned dimensions of TE can be observed, due to the differences in the SL and TL systems, he can decide to sacrifice certain dimensions while promoting others. These strategic decisions are made on the basis of what type of text is being translated and for whom. For instance in translating the Holy Quran or Holy Bible, depending on one's target audience, the translation strategies may differ. If the translation is addressed to a lay-man, the SL textual arrangement need not be preserved in TL because what would be of primary interest would be the core message. But if it is addressed to a religious scholar or theologian, the actual SL textual arrangements would have to be preserved because for such an audience "the way of say" would also be of interest in understanding the nature of the message.

\section{REFERENCES}

CANALE, M. and M. SWAIN (1980) : "Theoretical Bases of "Communicative Approaches to Second Language Teaching and Testing"', Applied Linguistics, 1.

FAERCH, G. and G. KASPER (1984) : Strategies in Interlanguage Communication, Longman.

HALLIDAY, M.A.K. and R. HASAN (1976) : Cohesion in English, Longman.

LOTFIPOUR-SAEDI, K. (1990) : "Discourse Analysis and the Problem of Translation Equivalence", Meta, $35(2)$.

LOTFIPOUR-SAEDI, K. (1992a) : "Analysing Literary Discourse: Implications for Literary Translation", Meta, $37(2)$.

LOTFIPOUR-SAEDI, K. (1992b) : An Introduction to the Principles of Translation, Iran University Press. 